\title{
NOD1 expression is increased in the adipose tissue of women with gestational diabetes
}

\author{
Martha Lappas ${ }^{1,2}$ \\ 1Obstetrics, Nutrition and Endocrinology Group, Department of Obstetrics and Gynaecology, Mercy Hospital \\ for Women, University of Melbourne, Level 4/163 Studley Road, Heidelberg, Victoria 3084, Australia \\ ${ }^{2}$ Mercy Perinatal Research Centre, Mercy Hospital for Women, Heidelberg, Victoria, Australia
}

Correspondence should be addressed to M Lappas

Email

mlappas@unimelb.edu.au

\begin{abstract}
Maternal peripheral insulin resistance and increased inflammation are two features of pregnancies, complicated by gestational diabetes mellitus (GDM). The nucleotide-binding oligomerisation domain (NOD) intracellular molecules recognise a wide range of microbial products, as well as other intracellular danger signals, thereby initiating inflammation through activation of nuclear factor $\kappa B(N F \kappa B)$. The aim of this study was to determine whether levels of NOD1 and NOD2 are increased in adipose tissue of women with GDM. The effect of NOD1 and NOD2 activation on inflammation and the insulin signalling pathway was also assessed. NOD1, but not NOD2, expression was higher in omental and subcutaneous adipose tissues obtained from women with GDM when compared with those from women with normal glucose tolerance (NGT). In both omental and subcutaneous adipose tissues from NGT and GDM women, the NOD1 ligand g-D-glutamyl-meso-diaminopimelic acid (iE-DAP) significantly induced the expression and secretion of the pro-inflammatory cytokine interleukin 6 (IL6) and chemokine IL8; COX2 (PTGS2) gene expression and subsequent prostaglandin production; the expression and secretion of the extracellular matrix remodelling enzyme matrix metalloproteinase 9 (MMP9) and the gene expression and secretion of the adhesion molecules ICAM1 and VCAM1. There was no effect of the NOD2 ligand muramyl dipeptide on any of the endpoints tested. The effects of the NOD1 ligand iE-DAP were mediated via NFKB, as the NFKB inhibitor BAY 11-7082 significantly attenuated iE-DAP-induced expression and secretion of pro-inflammatory cytokines, COX2 gene expression and subsequent prostaglandin production, MMP9 expression and secretion and ICAM1 and VCAM1 gene expression and secretion. In conclusion, the present findings describe an important role for NOD1 in the development of insulin resistance and inflammation in pregnancies complicated by GDM.
\end{abstract}
Key Words
- adipose tissue
- gestational diabetes
- NOD1
- inflammation
- insulin resistance

Journal of Endocrinology (2014) 222, 99-112

\section{Introduction}

Gestational diabetes mellitus (GDM) is characterised as any degree of glucose intolerance with first recognition during pregnancy. It is the most common type of diabetes found in pregnancy, affecting up to $14 \%$ of all pregnancies (Kim et al. 2007); the prevalence of GDM is increasing worldwide, in part due to the increased rates of obesity (Ferrara 2007). Of clinical significance, there are short- and long-term consequences for both mother and infant (Dabelea et al. 2000, Sobngwi et al. 2003), enhancing the susceptibility to a number of chronic diseases including 
obesity, diabetes, cardiovascular disease and certain cancers later in life.

There is now increasing evidence that the obese and diabetic environment may induce a number of changes in maternal adipose tissue, which may play an important role in the growth and development of the foetus. For example, maternal adipose tissue's insulin resistance, an important adaptation that occurs in the later part of pregnancy, is even more pronounced in women with GDM (Catalano et al. 2002, Colomiere et al. 2010), resulting in greater foetal substrate availability and thus enhanced adiposity (Lain \& Catalano 2007). Maternal adipose tissue also synthesises and secretes a number of inflammatory mediators, which are dysregulated in obese and GDM pregnancies, that have been shown to correlate with foetal adiposity (Kautzky-Willer et al. 1997, Krauss et al. 2002, Radaelli et al. 2006).

Toll-like receptors and nucleotide-binding oligomerisation domain containing protein-like receptor (NLR) are the two families of pattern recognition receptors (PRRs) that play critical roles in inflammation. The two prominent members of the NLRs are the cytosolic PRRs NOD1 and NOD2. Their activation, by bacterial peptidoglycans, results in nuclear factor $\kappa \mathrm{B}(\mathrm{NF} \kappa \mathrm{B})$-induced gene transcription. Recently, NOD1 and NOD2 have been shown to play an important role in inflammation and insulin resistance in adipocytes (Winzer et al. 2004, Yi-Jun et al. 2012, Zhao et al. 2011, Zhou et al. 2012, Purohit et al. 2013). The levels of NOD1 and NOD2 mRNA are markedly increased in differentiated murine 3T3-L1 adipocytes and human primary adipocyte cultures upon adipocyte conversion. Moreover, Nod1 mRNA is markedly increased only in the fat tissues of diet-induced obese mice (Zhao et al. 2011). The Nod1/2 knockout mice are protected from high-fat-diet-induced inflammation, lipid accumulation and peripheral insulin intolerance (Schertzer et al. 2011). Conversely, direct activation of NOD1 protein causes insulin resistance (Schertzer et al. 2011, Zhao et al. 2011, Zhou et al. 2012). Activation of NOD1 also induces the expression and/or secretion of a number of pro-inflammatory mediators from adipocytes (Garvey et al. 1993, Lappas 2013a, Purohit et al. 2013).

Given that obesity and GDM share many common features, it is possible that in GDM, the activation of NOD1 and NOD2 in adipose tissue may enhance inflammation and induce insulin resistance; two key features of this disease. However, the expression and regulation of NOD1 and NOD2 in adipose tissues of pregnant women have not yet been investigated. Thus, the aim of this study was to determine the effect of pre-existing maternal obesity and
GDM on NOD1 and NOD2 gene expression in subcutaneous and omental adipose tissues. To determine whether NOD1 and NOD2 induce markers of inflammation and interfere with the insulin signalling pathway, the effect of the NOD1 ligand g-D-glutamyl-meso-diaminopimelic acid (iE-DAP) and the NOD2 ligand muramyl dipeptide (MDP) was examined in subcutaneous and omental adipose tissues of pregnant women.

\section{Materials and methods}

\section{Tissue collection and preparation}

Human subcutaneous and omental adipose tissues were obtained (with the approval of the Research Ethics Committee of Mercy Health) from consenting women who delivered healthy, singleton infants at term $(>37$ weeks gestation).

Human subcutaneous (from the anterior abdominal wall) and omental adipose tissues were obtained from a total of 46 pregnant women (28 normal glucose tolerance (NGT) and 18 GDM). The tissues were obtained within 15 min of delivery and the dissected fragments were thoroughly washed in ice-cold PBS to remove any blood, snap frozen in liquid nitrogen and either stored at $-80^{\circ} \mathrm{C}$ until required for RNA extraction for gene expression analysis by quantitative RT-PCR (qRT-PCR), or immediately used for explant studies as detailed below. All tissues were obtained at the time of term Caesarean section before the onset of labour. Indications for Caesarean section included repeat Caesarean section or breech presentation. Women with any adverse underlying medical condition (i.e. including asthma, preeclampsia and pregestational diabetes) were excluded. Samples were collected from lean (BMI $<24.9 \mathrm{~kg} / \mathrm{m}^{2}$ ), overweight (BMI between 25 and $29.9 \mathrm{~kg} / \mathrm{m}^{2}$ ) and obese (BMI $>30 \mathrm{~kg} / \mathrm{m}^{2}$ ) subjects. The women were classified as lean, overweight or obese based on their BMI, calculated at their first antenatal visit at approximately 12 weeks gestation. Women with GDM were diagnosed according to the criteria of the Australasian Diabetes in Pregnancy Society (ADIPS) by either a fasting venous plasma glucose level of $\geq 5.5 \mathrm{mmol} / 1$ glucose and/or $\geq 8.0 \mathrm{mmol} / 1$ glucose $2 \mathrm{~h}$ after a $75 \mathrm{~g}$ oral glucose load at approximately $26-28$ weeks gestation. All women with GDM were prescribed insulin in addition to dietary management. All pregnant women were screened for GDM, and women in the NGT group had a negative screening result. The relevant clinical details of the subjects are detailed elsewhere (Lappas 2014a).

Published by Bioscientifica Ltd 


\section{Tissue explant culture}

Subcutaneous and omental adipose tissue explants were also examined to determine the effect of the NOD1 ligand iE-DAP and the NOD2 ligand MDP on inflammation. For these studies, subcutaneous and omental adipose tissues were obtained from NGT pregnant women ( $n=6$ patients) and women with GDM ( $n=6$ patients). Adipose tissue explants were produced as described previously (Lappas 2013a). Tissue explants were incubated, for $20 \mathrm{~h}$, in the absence or presence of $5 \mu \mathrm{g} / \mathrm{ml}$ iE-DAP or $5 \mu \mathrm{g} / \mathrm{ml}$ MDP (purchased from Life Research, Scoresby, VIC, Australia). The concentrations of iE-DAP and MDP were based on results from past studies (Lappas 2013b). In order to determine whether iE-DAP and MDP regulate inflammation via $\mathrm{NF} \kappa \mathrm{B}$, additional experiments were also carried out whereby tissues from NGT pregnant women were pretreated with $50 \mu \mathrm{M}$ BAY 11-7082 for $60 \mathrm{~min}$ before the addition of iE-DAP and MDP for $20 \mathrm{~h}$. The concentration of BAY 11-7082 was based on results from previously published studies (Lappas 2013b). At this dose, there was no effect of BAY 11-7082 on basal cytokine secretion (data not shown). After final incubation, tissue and media were collected separately and stored at $-80{ }^{\circ} \mathrm{C}$ for further analysis as detailed below.

\section{Glucose uptake}

Subcutaneous and omental adipose tissue explants from NGT pregnant women were generated as detailed earlier and glucose uptake in adipose tissue was measured as described previously (Lappas et al. 2012). Briefly, after final incubation with treatment agents, tissues were pre-incubated in the absence or presence of $20 \mu \mathrm{M}$ cytochalasin B in Krebs buffer for 5 min. 2-Deoxy-D-glucose (2DG) uptake was measured by adding $3 \mu \mathrm{Ci} / \mathrm{ml}\left[{ }^{14} \mathrm{C}\right]-2 \mathrm{DG}$ (PerkinElmer, Glen Waverley, VIC, Australia) and $1 \mathrm{mM} 2 \mathrm{DG}$ to Krebs buffer containing $0.1 \%$ BSA (fatty acid free) and $0.1 \mu \mathrm{M}$ insulin for $20 \mathrm{~min}$. Tissues were immediately collected and washed in ice-cold PBS three times and solubilised for $4 \mathrm{~h}$ in $1 \mathrm{M} \mathrm{NaOH}$ at $60^{\circ} \mathrm{C}$. Tissues were neutralised with $1 \mathrm{M} \mathrm{HCl}$ and then centrifuged at $15000 \boldsymbol{g}$ for $5 \mathrm{~min}$ to pellet insoluble material. The supernatant was transferred to a vial containing $3 \mathrm{ml}$ of liquid scintillation fluid. All samples were counted for radioactivity in a liquid scintillation counter. GLUT-specific glucose uptake was measured by subtracting values for $\left[{ }^{14} \mathrm{C}\right]$ $2 \mathrm{DG}$ uptake in the presence of $20 \mu \mathrm{M}$ cytochalasin $\mathrm{B}$. The rate of $\left[{ }^{14} \mathrm{C}\right]-2 \mathrm{DG}$ transport was expressed in nanomoles per minute per milligram protein. Fold change was calculated relative to basal levels, which were set at 1 .

\section{RNA extraction and qRT-PCR}

Total RNA was extracted from tissues using TRIsure according to the manufacturer's instructions (Bioline, Alexandria, NSW, Australia). RNA concentration and purity were measured using a NanoDrop ND1000 spectrophotometer (Thermo Scientific, Pittsburgh, PA, USA). RNA was converted to cDNA using the SuperScript VILO cDNA synthesis Kit (Invitrogen) according to the manufacturer's instructions. The cDNA was diluted to 50-fold, and $4 \mu \mathrm{l}$ of this was used to perform RT-PCR using SensiFAST SYBR (Bioline) and $100 \mathrm{nM}$ of pre-designed and validated primers. Primers were purchased from either Qiagen (QuantiTect primer assays) or Integrated DNA Technologies (PrimeTime qPCR Assays). The RT-PCR was carried out using a CFX384 real-time PCR detection system from Bio-Rad Laboratories. Average gene threshold cycle $(\mathrm{Ct})$ values were normalised to the average GAPDH $C t$ values of the same cDNA sample. Fold differences were determined using the comparative $C t$ method and shown as mean \pm S.E.M. of relative gene expression. For the explant studies, there was a large variability of baseline values, which is normal for tissues derived from different patients. Thus, fold change was calculated relative to either basal levels or levels with iE-DAP, which were set at 1 .

\section{Western blotting analysis}

Tissue lysates were prepared and western blotting was performed as described previously (Lappas et al. 2005a). Rabbit polyclonal anti-phosphorylated IRS-1 (Tyr1229), rabbit polyclonal anti-IRS-1 (A19), and rabbit polyclonal anti-GLUT4 (H61) were purchased from Santa Cruz Biotechnology. Samples $(40 \mu \mathrm{g})$ of protein were separated on polyacrylamide gels (Bio-Rad Laboratories) and transferred to nitrocellulose. Protein expression was identified by comparison with the mobility of a protein standard. The membranes were viewed and analysed using the Chemi-Doc system (Bio-Rad). Semi-quantitative analysis of the relative density of the bands in western blots was performed using Quantity One 4.2.1 Image Analysis Software (Bio-Rad). Data were corrected for background, normalised to $\beta$-actin (mouse monoclonal anti- $\beta$-actin (A5316; Sigma) and fold change was calculated relative to basal levels, which were set at 1 .

\section{Enzyme immunoassays}

The release of interleukin 6 (IL6) and IL8 was examined by sandwich ELISA according to the manufacturer's

Published by Bioscientifica Ltd. 

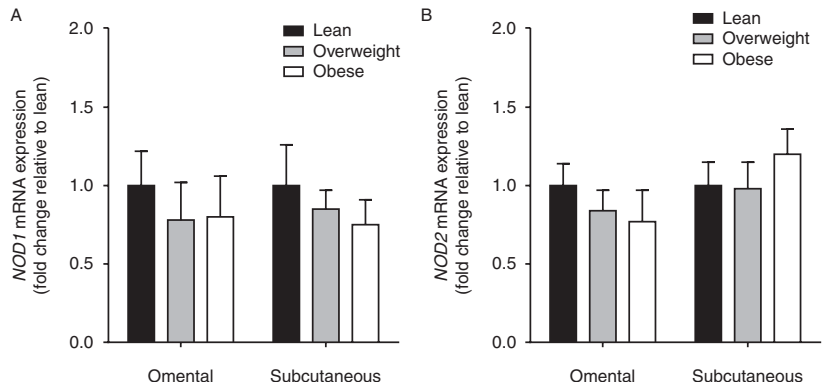

Figure 1

NOD1 is increased in adipose tissues of women with GDM. (A and B) Omental and subcutaneous adipose tissues were obtained from lean ( $n=10$ subjects), overweight ( $n=8$ subjects) and obese ( $n=10$ subjects) pregnant women at the time of term Caesarean section. NOD1 and NOD2 mRNA expression was normalised to actin mRNA expression. Fold changes were calculated relative to the level for the lean group, and data are displayed as mean \pm s.E.M. (C and D) Omental and subcutaneous adipose

instructions (Invitrogen). The release of PGE2 and PGF2 $\alpha$ into the incubation medium was assayed using a commercially available competitive enzyme immunoassay kit according to the manufacturer's specifications (Kookaburra Kits from Sapphire Bioscience, Waterloo, NSW, Australia). The concentration of sICAM1 and sVCAM1 in the media was measured by sandwich ELISA according to the manufacturer's instructions (R\&D
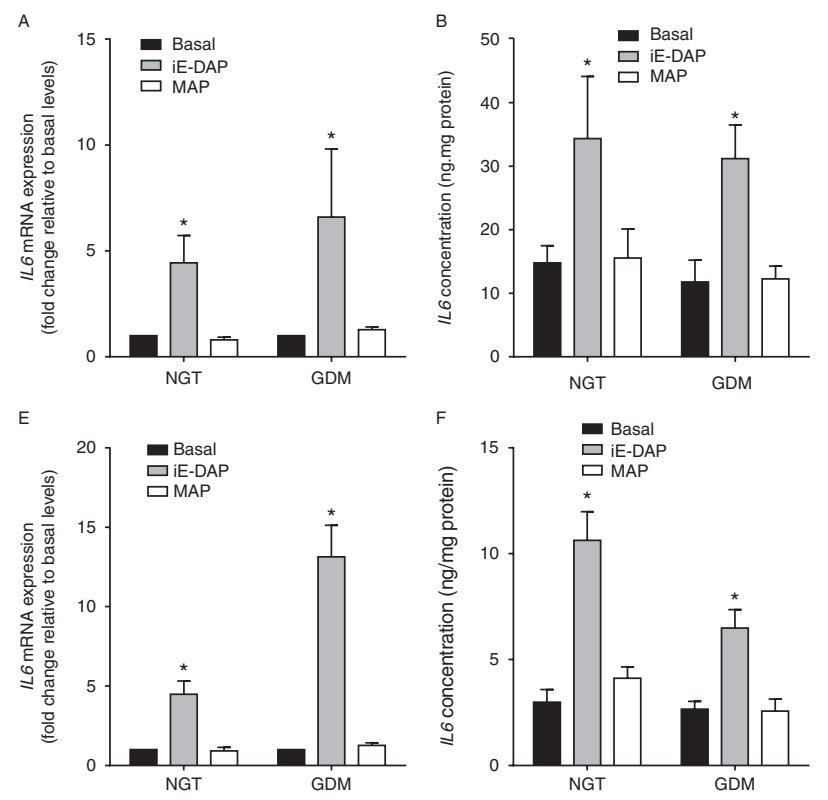

Figure 2

The NOD1 ligand iE-DAP induces pro-inflammatory cytokines in adipose tissues of pregnant women. (A, B, C and D) Omental and (E, F, G and H) subcutaneous adipose tissues were incubated in the absence or presence of $5 \mu \mathrm{g} / \mathrm{ml} \mathrm{iE}$-DAP or $5 \mu \mathrm{g} / \mathrm{ml}$ MDP for $20 \mathrm{~h}(n=6$ NGT patients and $n=6 \mathrm{GDM}$ patients). (A, C, E and G) Expression of IL6 and IL8 was analysed by qRT-PCR. Gene expression was normalised to GAPDH mRNA expression and the fold
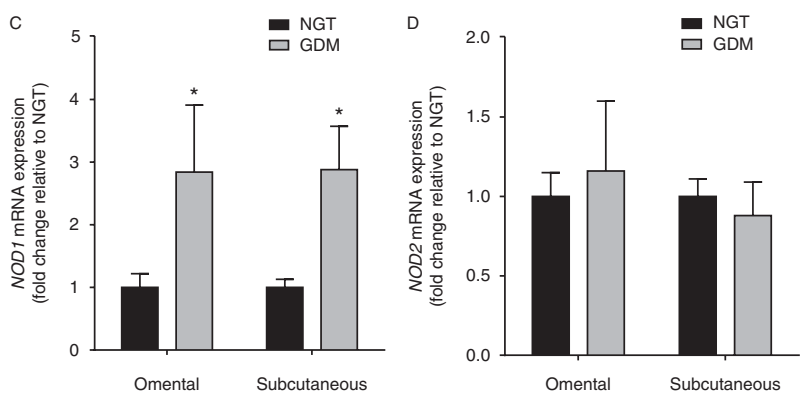

tissues were obtained from NGT ( $n=18$ subjects; eight overweight and ten obese) and GDM ( $n=18$ subjects; eight overweight and ten obese) pregnant women at the time of term Caesarean section. NOD1 and NOD2 mRNA expression were normalised to actin mRNA expression. Fold changes were calculated relative to NGT, and data are displayed as mean \pm S.E.M. $* P<0.05$ vs NGT mRNA expression ( $t$-test).

Systems Inc., Minneapolis, MN, USA). All data were corrected for total protein and expressed as either picograms or nanograms per milligram protein. The protein content of tissue homogenates was determined using BCA protein assay (Pierce, Rockford, IL, USA), using BSA as a reference standard, as described previously (Lappas et al. 2005b). The calculated interassay and intraassay coefficients of variation were all $<10 \%$.
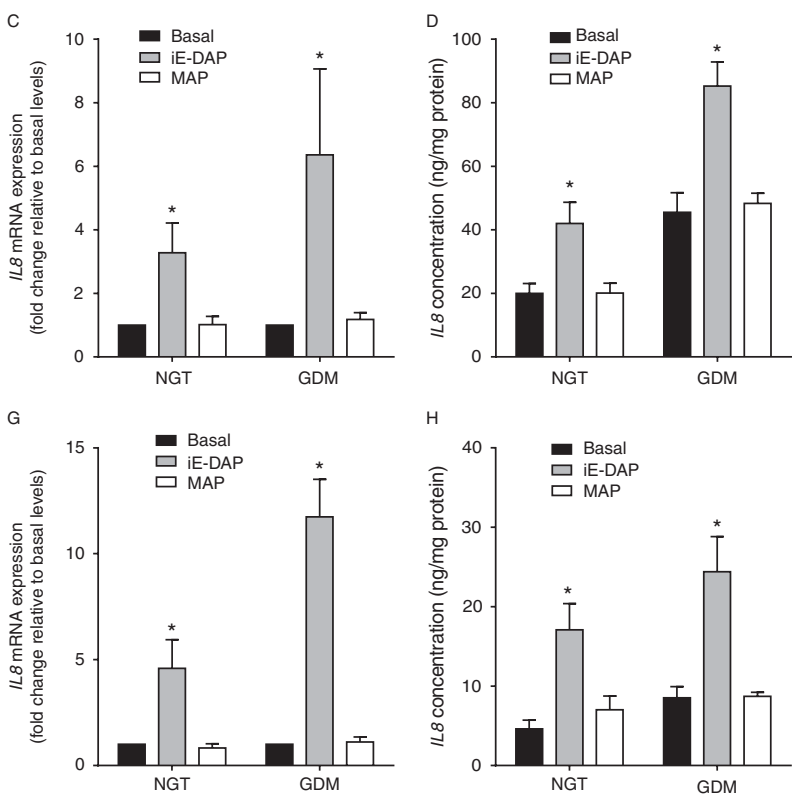

changes were calculated relative to basal levels. Data are displayed as mean \pm S.E.M. ${ }^{*} P<0.05$ vs basal (paired-sample comparison). (B, $D, F$ and $H$ ) The incubation medium was assayed by ELISA for the concentration of IL6 and IL8. Each bar represents the mean \pm S.E.M. ${ }^{*} P<0.05$ vs basal (paired-sample comparison). 
A

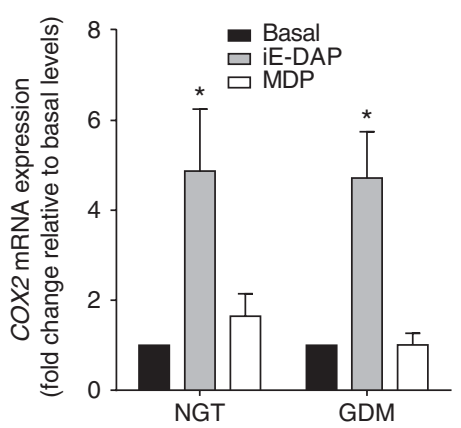

D

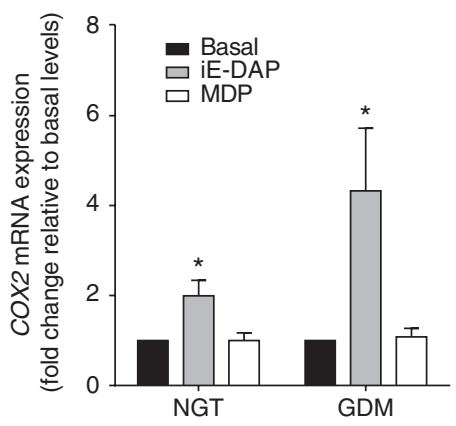

$\mathrm{B}$

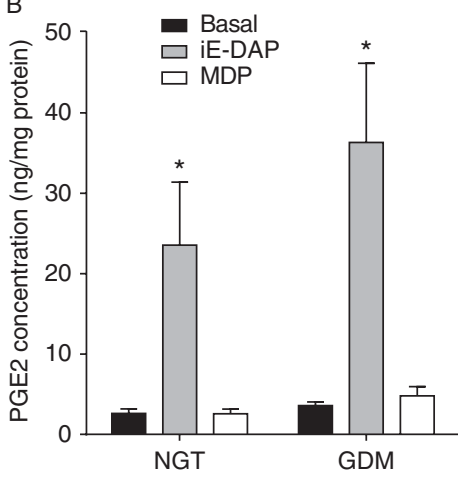

$\mathrm{E}$

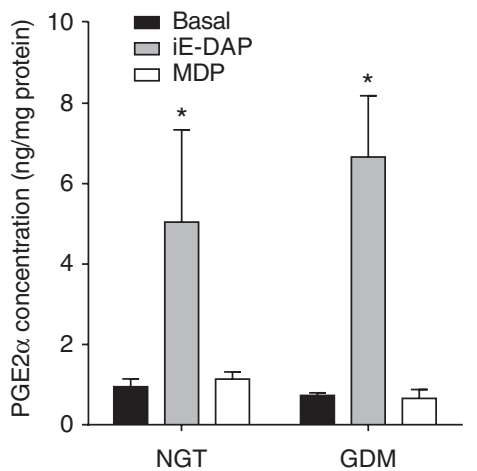

$\mathrm{C}$

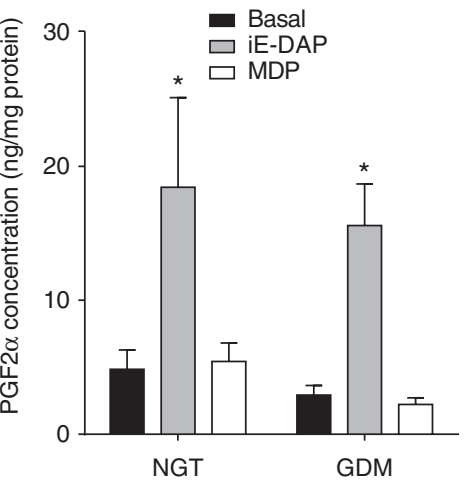

$\mathrm{F}$

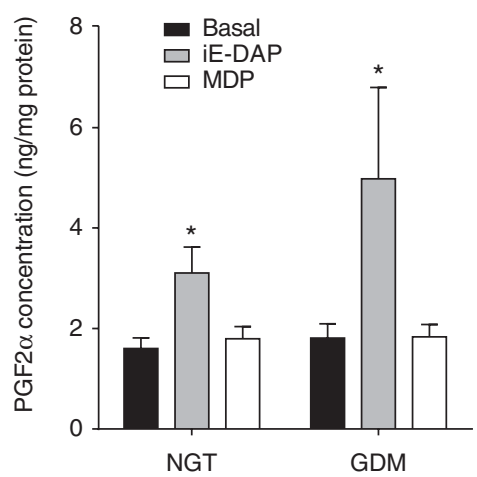

Figure 3

The NOD1 ligand iE-DAP induces COX2 and subsequent prostaglandin production in adipose tissues of pregnant women. (A, B and C) Omental and $(D, E$ and $F$ ) subcutaneous adipose tissues were incubated in the absence or presence of $5 \mu \mathrm{g} / \mathrm{ml} \mathrm{iE}-\mathrm{DAP}$ or $5 \mu \mathrm{g} / \mathrm{ml}$ MDP for $20 \mathrm{~h}$ ( $n=6 \mathrm{NGT}$ patients and $n=6$ GDM patients). (A and D) COX2 gene expression was analysed by qRTPCR. Gene expression was normalised to GAPDH mRNA expression and the

\section{Gelatin zymography}

Matrix metalloproteinase 9 (MMP9) activity was assessed by gelatin zymography as described previously (Lappas et al. 2006) on conditioned media collected from tissue explants. Proteolytic activity was visualised as clear zones of lysis on a blue background of undigested gelatin. Gels were scanned (ChemiDoc; Bio-Rad Laboratories), inverted, and densitometry was performed using Quantity One image analysis software (Bio-Rad Laboratories). Fold change was calculated relative to either basal levels or levels with iE-DAP, which was set at 1 .

\section{Statistical analysis}

Statistical analysis was performed on the normalised data unless otherwise specified. All statistical analyses were undertaken using GraphPad Prism (GraphPad Software, La Jolla, CA, USA). Two-sample comparisons, either a paired fold changes were calculated relative to basal levels. Data are displayed as mean \pm s.E.M. ${ }^{*} P<0.05$ vs basal (paired-sample comparison). (B, C, E and F) The incubation medium was assayed by EIA for concentration of PGE2 and PGF2 $\alpha$. Each bar represents the mean \pm S.E.M. ${ }^{\star} P<0.05$ vs basal (pairedsample comparison).

or unpaired Student's $t$-test, were used to assess statistical significance between normally distributed data; otherwise, the nonparametric Mann-Whitney $U$ (unpaired) or the Wilcoxon (matched pairs) tests were used. For all other comparisons, the homogeneity of data was assessed by the Bartlett test, and when significant, the data were logarithmically transformed before further analysis using a one-way ANOVA (using least significant difference correction to discriminate among the means). Statistical significance was ascribed to $P$ value $<0.05$. Data were expressed as mean \pm s.E.M.

\section{Results}

\section{NOD1 expression is increased in adipose tissue of} women with GDM

Demographic data of all participants involved in the investigation are detailed elsewhere (Lappas 2014a). 

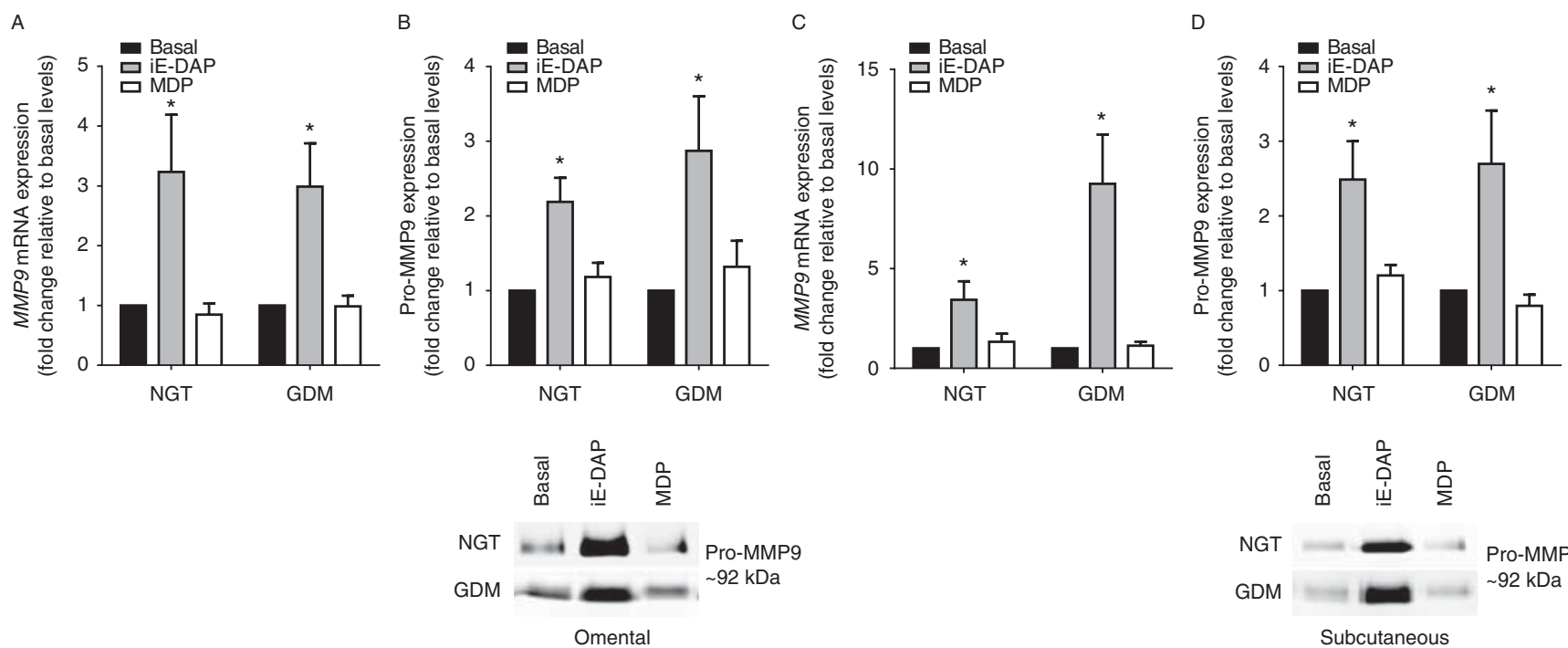

The NOD1 ligand iE-DAP induces ECM matrix remodelling enzymes in adipose tissues of pregnant women. ( $A$ and $B$ ) Omental and ( $C$ and $D$ ) subcutaneous adipose tissues were incubated in the absence or presence of $5 \mu \mathrm{g} / \mathrm{ml}$ iE-DAP or $5 \mu \mathrm{g} / \mathrm{ml}$ MDP for $20 \mathrm{~h}$ ( $n=6 \mathrm{NGT}$ patients and $n=6 \mathrm{GDM}$ patients). (A and C) MMP9 expression was analysed by qRT-PCR. Gene expression was normalised to GAPDH mRNA expression and the fold changes were calculated relative to basal levels. Data are displayed as

In the lean, overweight and obese cohort, there were no significant differences in maternal age, gestational age and foetal birth weight between any of the groups studied. For the NGT vs GDM cohort, all samples where obtained from women who were either overweight or obese (the NGT and the GDM cohorts consisted of eight overweight and ten obese patients each). Again, there were no significant differences in maternal age, maternal BMI, gestational age and foetal birth weight between the GDM and NGT women.

There was no effect of pre-existing maternal obesity on NOD1 or NOD2 expression in omental or subcutaneous adipose tissue (Fig. 1A and B). mRNA expression of NOD1 was significantly higher in omental and subcutaneous adipose tissues obtained from women with GDM (Fig. 1C). On the other hand, adipose tissue NOD2 expression was not different between NGT and GDM women (Fig. 1D).

\section{Effect of NOD1 ligand iE-DAP and NOD2 ligand MDP on markers of inflammation in pregnant adipose tissue}

The next aim was to determine whether NOD1 and NOD2 regulate pro-inflammatory mediators in subcutaneous and omental adipose tissues. This was done by incubating mean \pm s.E.M. ${ }^{*} P<0.05$ vs basal (paired-sample comparison). (B and $D$ ) Representative zymography demonstrating pro-MMP9 expression from omental and subcutaneous adipose tissues from one patient. MMP9 expression levels were confirmed by densitometry. The fold changes were calculated relative to basal levels. Each bar represents the mean \pm s.E.M. $* P<0.05$ vs basal (paired-sample comparison).

tissues with the NOD1 agonist iE-DAP and the NOD2 agonist MDP for $20 \mathrm{~h}$. Adipose tissue was obtained from women with NGT and women with GDM. Enzyme immunoassays were used to determine the release of the pro-inflammatory cytokine IL6; the chemokine IL8; the prostaglandins PGE2, PGF2 $\alpha$ and PGI2; and the adhesion molecule sICAM1 and sVCAM1. The expression of secretory pro MMP2 and pro MMP9 was measured by gelatin zymography. Gene expression for these analytes was assessed by qRT-PCR.

As shown in Fig. 2A, B, C, D, E and F, iE-DAP significantly increased the gene expression of the proinflammatory cytokine IL6 and the chemokine IL8 (CXCL8). This was associated with significantly increased release of IL6 and IL8 from omental and subcutaneous adipose tissues. On the other hand, there was no effect of the NOD2 ligand on cytokine expression or secretion.

Expression of COX2 gene and subsequent PGE2 and PGF2 $\alpha$ release from omental and subcutaneous adipose tissues were also significantly increased by treatment with the NOD1 ligand iE-DAP (Fig. 3A, B, C, D, E and F). Again, COX2 expression and prostaglandin release were not affected by treatment with MDP.

MMPs are involved in the remodelling and/or degradation of the extracellular matrix (ECM). In this study,

Published by Bioscientifica Ltd. 

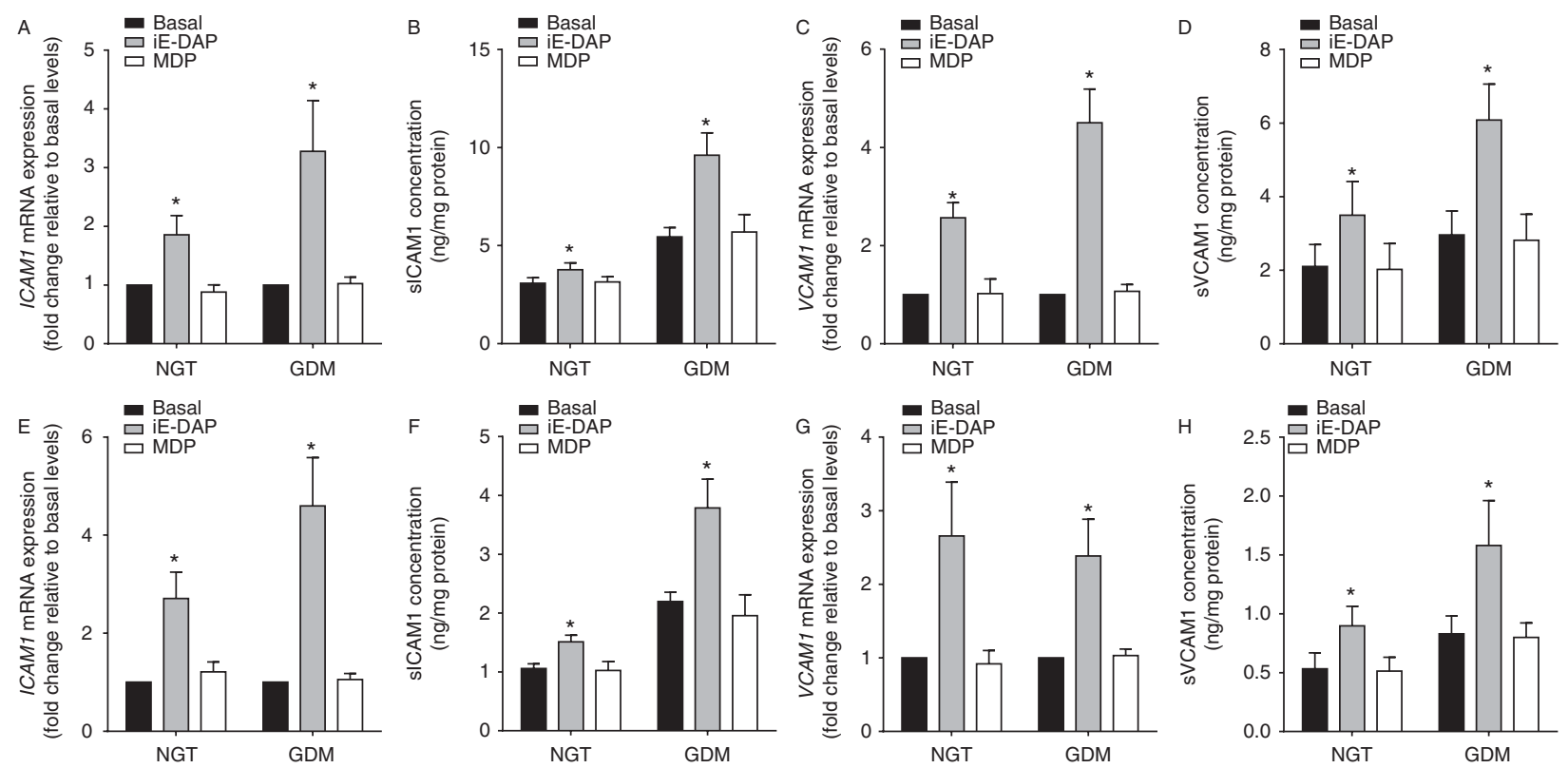

Figure 5

The NOD1 ligand iE-DAP induces the expression and secretion of adhesion molecules in adipose tissues of pregnant women. (A, B, C and D) Omental and $(E, F, G$ and $H)$ subcutaneous adipose tissues were incubated in the absence or presence of $5 \mu \mathrm{g} / \mathrm{ml}$ iE-DAP or $5 \mu \mathrm{g} / \mathrm{ml}$ MDP for $20 \mathrm{~h}(n=6$ patients). (A, C, E and G) Expression of ICAM1 and VCAM1 was analysed by qRT-PCR. Gene expression was normalised to GAPDH mRNA expression and

adipose tissue MMP9 gene expression and the release of pro MMP9 enzyme activity were significantly augmented by iE-DAP (Fig. 4A, B, C and D). On the other hand, NOD2 activation by MDP had no effect on MMP9 expression or release. There was no effect of iE-DAP or MDP on MMP9 gene expression and pro MMP2 secretion (data not shown).
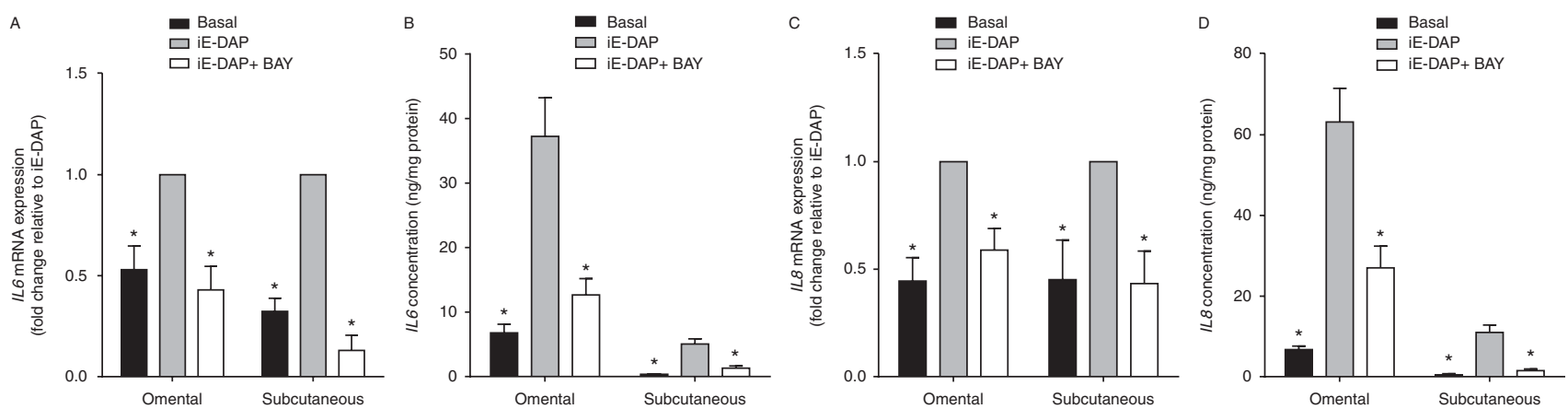

Figure 6

The NOD1 ligand iE-DAP increases pro-inflammatory cytokines via the NFKB pathway. Omental and subcutaneous adipose tissues from NGT pregnant women were pre-incubated in the absence or presence of $50 \mu \mathrm{M} \mathrm{BAY}$ 11-7082 for $60 \mathrm{~min}$ and then treated with $5 \mu \mathrm{g} / \mathrm{ml}$ iE-DAP for $20 \mathrm{~h}(n=6$ patients). (A and C) Expression of IL6 and IL8 genes was analysed by qRT-PCR.

the fold changes were calculated relative to basal levels. Data are displayed as mean \pm S.E.M. ${ }^{*} P<0.05$ vs basal (paired-sample comparison). (B, D, F and $\mathrm{H})$ The incubation medium was assayed by ELISA for the concentration of sICAM 1 and sVCAM1. Each bar represents the mean \pm s.E.M. ${ }^{\star} P<0.05$ vs basal (paired-sample comparison).

The expression of the genes encoding the adhesion molecules ICAM1 and VCAM1 was significantly amplified in the presence of the NOD1 ligand iE-DAP (Fig. 5A, C, $\mathrm{E}$ and $\mathrm{G})$. This was associated with significantly increased secretion of sICAM1 and sVCAM1 (Fig. 5B, D, F and H). Again, there was no effect of the NOD2 ligand MDP.
Gene expression was normalised to GAPDH mRNA expression and the fold changes were calculated relative to iE-DAP. Data are displayed as mean \pm S.E.M. $* P<0.05$ vs iE-DAP (one-way ANOVA). (B and $D$ ) The incubation medium was assayed by ELISA for the concentration of IL6 and IL8. Each bar represents the mean \pm S.E.M. ${ }^{*} P<0.05$ vs $\mathrm{iE}-\mathrm{DAP}$ (one-way ANOVA). 


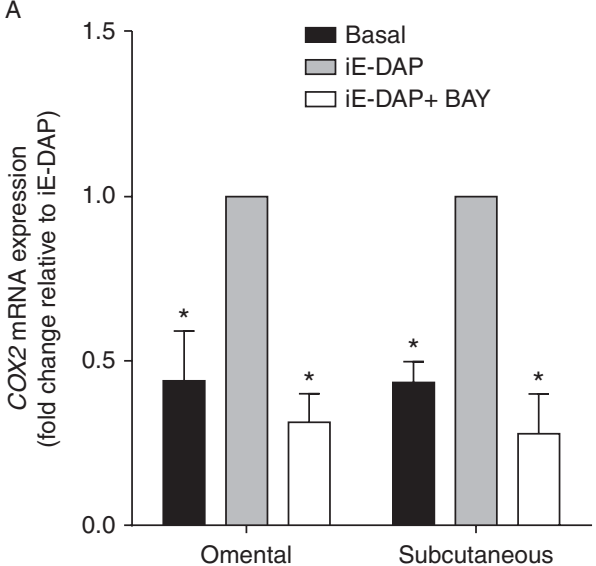

B

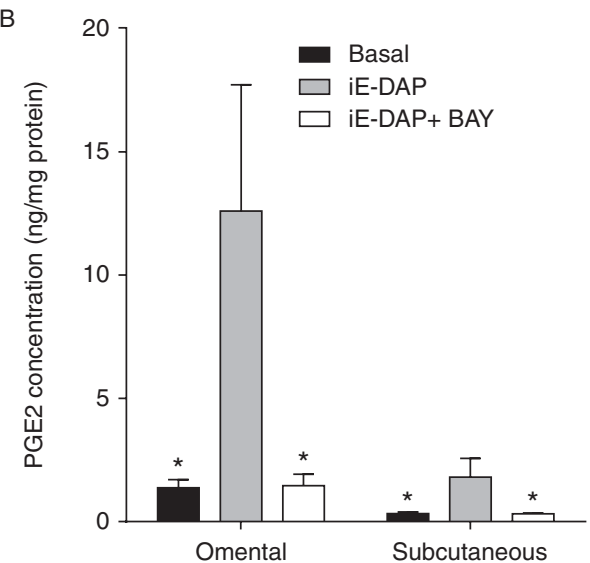

C

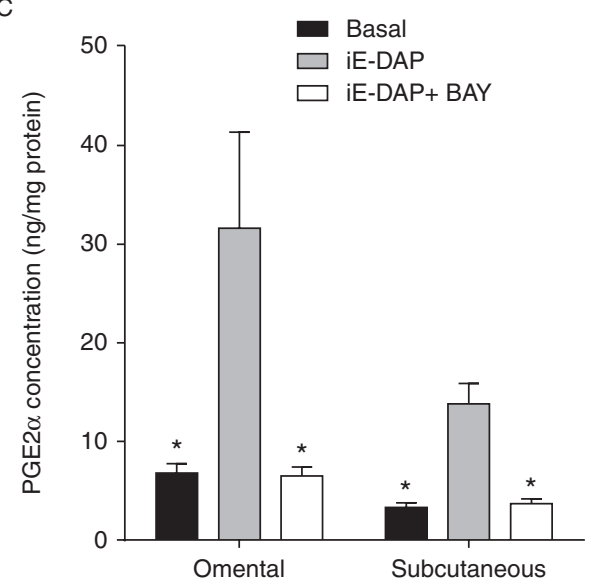

Figure 7

The NOD1 ligand iE-DAP increases the COX2 prostaglandin pathway via the NFKB pathway. Omental and subcutaneous adipose tissues from NGT pregnant women were pre-incubated in the absence or presence of $50 \mu \mathrm{M}$ BAY 11-7082 for $60 \mathrm{~min}$ and then treated with $5 \mu \mathrm{g} / \mathrm{ml}$ iE-DAP for $20 \mathrm{~h}$ ( $n=6$ patients). (A) COX2 gene expression was analysed by qRT-PCR. Gene expression was normalised to GAPDH mRNA expression and the fold changes were calculated relative to iE-DAP. Data are displayed as mean \pm s.E.M. ${ }^{*} P<0.05$ vs iE-DAP (one-way ANOVA). (B and C) The incubation medium was assayed by EIA for concentration of PGE2 and PGF $2 \alpha$. Each bar represents the mean \pm s.E.M. ${ }^{*} P<0.05$ vs iE-DAP (one-way ANOVA).

\section{The NOD1 ligand iE-DAP regulates inflammation via NFKB}

The next aim was to explore whether the NOD1 agonist iE-DAP regulates pro-inflammatory mediators in adipose tissue or pregnant women via NFKB. To address this, experiments were conducted in which omental or subcutaneous adipose tissues were pre-incubated for 60 min with the NFאB inhibitor BAY 11-7082 before stimulation with iE-DAP for $20 \mathrm{~h}$. In both omental and subcutaneous adipose tissues, BAY 11-7082 significantly attenuated iE-DAP-induced cytokine gene expression (Fig. 6A and C) and release (Fig. 6B and D) COX2 mRNA expression (Fig. 7A) and the resultant PGE2 and PGF2 $\alpha$ release (Fig. 7B and C); MMP9 gene expression (Fig. 8A) and enzyme activity (Fig. 8B); and ICAM1 and VCAM1 mRNA expression (Fig. 9A and C) and sICAM1 and sVCAM1 secretion (Fig. 9B and D).

\section{The NOD1 ligand iE-DAP impairs insulin signalling in pregnant omental adipose tissue}

In women with GDM, expression of GLUT4 (SLC2A4) gene and subsequent glucose uptake are lower in adipose tissue (Garvey et al. 1993, Colomiere et al. 2010). Given that NOD1 expression was higher in adipose tissue obtained from women with GDM, the next aim of this study was to determine the effect of the NOD1 ligand iE-DAP on insulin signalling in adipose tissue from pregnant women. For these studies, only omental adipose tissue was used, as glucose uptake was very low in subcutaneous adipose tissue. The data depicted in Fig. 10 indicate that iE-DAP significantly decreased the expression of phosphorylated IRS1 protein, GLUT4 mRNA, GLUT4 protein and 2DG uptake.

\section{Discussion}

This study, for the first time, to my knowledge, demonstrates that NOD1 expression is increased in both subcutaneous and omental adipose tissues obtained from women with GDM when compared with BMI matched NGT women. Further to this, treatment of subcutaneous and omental adipose tissues from NGT and GDM pregnant women with the NOD1 ligand iE-DAP significantly increased the expression of a number of inflammatory markers. Specifically, there was an increase in the expression and secretion of the pro-inflammatory cytokine IL6, the pro-inflammatory chemokine IL8, COX2 and subsequent prostaglandin production, the ECM remodelling/degrading enzyme MMP9, and the

Published by Bioscientifica Ltd 

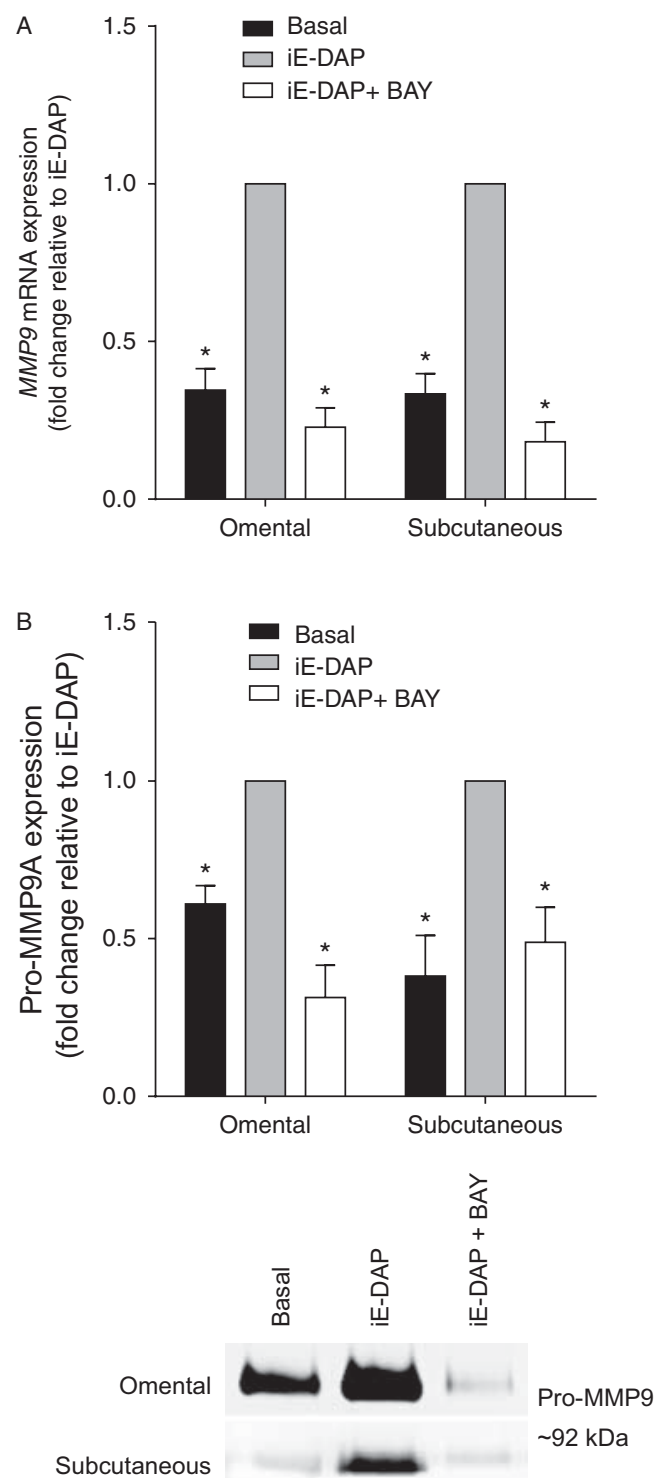

\section{Figure 8}

The NOD1 ligand iE-DAP regulates ECM matrix remodelling enzymes via the NFKB pathway. Omental and subcutaneous adipose tissues from NGT pregnant women were pre-incubated in the absence or presence of $50 \mu \mathrm{M}$ BAY 11-7082 for $60 \mathrm{~min}$ and then treated with $5 \mu \mathrm{g} / \mathrm{ml}$ iE-DAP for $20 \mathrm{~h}$ ( $n=6$ patients). (A) MMP9 gene expression was analysed by qRT-PCR. Gene expression was normalised to GAPDH mRNA expression and the fold change was calculated relative to iE-DAP. Data are displayed as mean \pm s.E.M. $* P<0.05$ vs iE-DAP (one-way ANOVA). (B) Representative zymography from one patient. MMP9 expression levels were confirmed by densitometry. The fold changes were calculated relative to iE-DAP. Each bar represents the mean \pm s.E.M. $* P<0.05$ vs iE-DAP (one-way ANOVA).

gene expression and secretion of the adhesion molecules ICAM1 and VCAM1. These effects of NOD1 appear to be mediated via the pro-inflammatory transcription factor $\mathrm{NF} \kappa \mathrm{B}$, as BAY 11-7082 ameliorated iE-DAP-induced inflammatory proteins. In addition, NOD1 activation of adipose tissue from pregnant women resulted in a decrease in insulin-stimulated glucose uptake. Collectively, these data indicate that NOD1 may contribute to the pathophysiology of GDM. Notably, there was no effect of GDM on the expression of NOD2 in both subcutaneous and omental adipose tissues. In addition, there was no effect of the NOD2 ligand on any of the inflammatory mediators or on the insulin signalling pathway.

When compared with NGT controls, NOD1 expression was increased in both omental and subcutaneous adipose tissues obtained from women with GDM. NOD2 expression was similar in the adipose tissues of NGT and GDM women. Although NOD1 and NOD2 mRNA are markedly increased during adipocyte differentiation (Zhao et al. 2011, Purohit et al. 2013), only NOD1 mRNA is markedly increased in adipose tissue in diet-induced obese mice (Zhao et al. 2011). Moreover, and in keeping with the findings of this study, only activation of NOD1, but not NOD2, dose-dependently suppresses 3T3-L1 adipocyte differentiation (Zhao et al. 2011, Purohit et al. 2013). Collectively, the findings of this study indicate that NOD2 is not active in adipose tissue of pregnant women. Indeed, NOD1 and NOD2 detect distinct structures of bacterial peptidoglycan. NOD1 recognises bacterial peptidoglycanderived peptides iE-DAP derived primarily from Gramnegative bacilli and particular Gram-positive bacteria (Chamaillard et al. 2003), whereas NOD2 recognises the minimal peptidoglycan MDP, the largest peptidoglycan motif common to all bacteria (Girardin et al. 2003). There is now some evidence that metabolic endotoxemia originating from the diet or the environment disrupts the balance between the immune and the metabolic systems (Cani et al. 2007) which may lead to GDM. Thus, it is possible that this increase in bacteria may activate NOD1, leading to the increased inflammation and insulin resistance observed in women with GDM (Garvey et al. 1993, Colomiere et al. 2010, Lappas 2013a, Oliva et al. 2013). Indeed, it has recently been shown that dietinduced modification of the gut flora with probiotics can ameliorate the insulin resistance and glucose homoeostasis of pregnant women (Laitinen et al. 2009).

Human adipose tissue is divided into two depots: the subcutaneous and the omental fat depot. They exhibit differences in their cellular composition, and metabolic and biochemical properties. For example, due to its direct access to the liver through the portal vein, omental adipose tissue is strongly associated with insulin resistance and type 2 diabetes (Fox et al. 2007). This study demonstrates that the NOD1 ligand iE-DAP significantly inhibits the insulin signalling pathway in omental adipose

Published by Bioscientifica Ltd. 

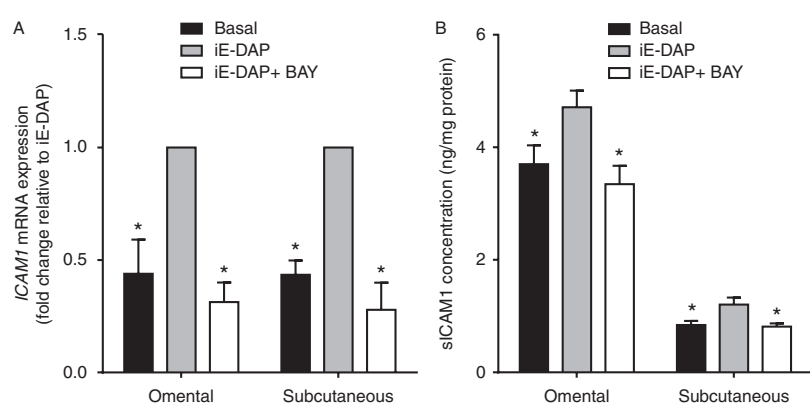

Figure 9

The NOD1 ligand iE-DAP increases expression of adhesion molecules via the NFKB pathway. Omental and subcutaneous adipose tissues from NGT pregnant women were pre-incubated in the absence or presence of $50 \mu \mathrm{M}$ BAY 11-7082 for $60 \mathrm{~min}$ and then treated with $5 \mu \mathrm{g} / \mathrm{ml}$ iE-DAP for $20 \mathrm{~h}(n=6$ patients). (A and C) ICAM1 and VCAM1 gene expression was analysed by qRT-PCR. Gene expression was normalised to GAPDH mRNA expression and

tissue of pregnant women, as evidenced by decreased phosphorylated IRS1, GLUT4 expression and glucose uptake. Thus, NOD1 may be one of the mechanisms causing the peripheral insulin resistance observed in GDM (Garvey et al. 1993, Colomiere et al. 2010). In agreement, other studies have also shown an important role for NOD1 in insulin action. In 3T3-L1 adipocytes and mature adipocytes, NOD1 activation suppresses insulin signalling by attenuating tyrosine phosphorylation and increases inhibitory serine phosphorylation of IRS1, resulting in decreased insulin-induced glucose uptake (Zhao et al. 2011, Purohit et al. 2013). These studies have been
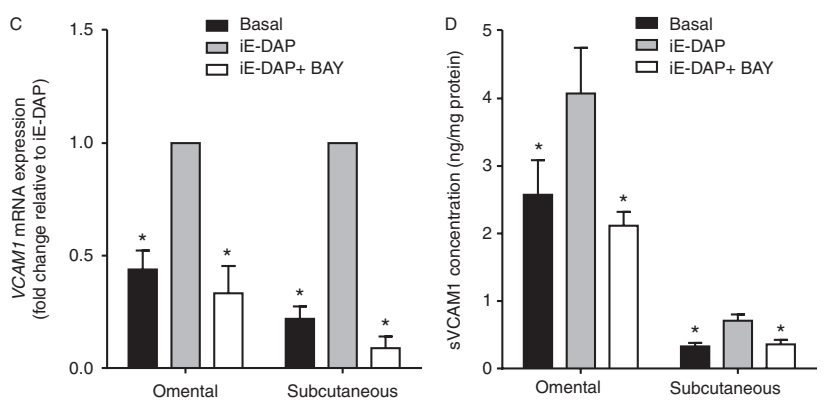

the fold changes were calculated relative to iE-DAP. Data are displayed as mean \pm s.E.M. ${ }^{*} P<0.05$ vs iE-DAP (one-way ANOVA). (B and D) The incubation medium was assayed by ELISA for concentration of SICAM1 and sVCAM1. Each bar represents the mean \pm s.E.M. ${ }^{*} P<0.05$ vs iE-DAP (one-way ANOVA).

supported by results from in vivo studies. In mice, the absence of NOD1 and NOD2 attenuates diet-induced insulin intolerance, and NOD1 ligands induce wholebody insulin resistance (Schertzer et al. 2011).

IL6 is one of several pro-inflammatory cytokines that have been associated with insulin resistance and type 2 diabetes (Kern et al. 2001, Pradhan et al. 2001, Senn et al. 2002, Nieto-Vazquez et al. 2008). High levels of IL6 are also associated with GDM (Yu et al. 2007, Kuzmicki et al. 2009, Morisset etal. 2011). CXC chemokines, such as IL8 (CXCL8), are among the most critical inflammatory mediators for the recruitment of neutrophils. Women with
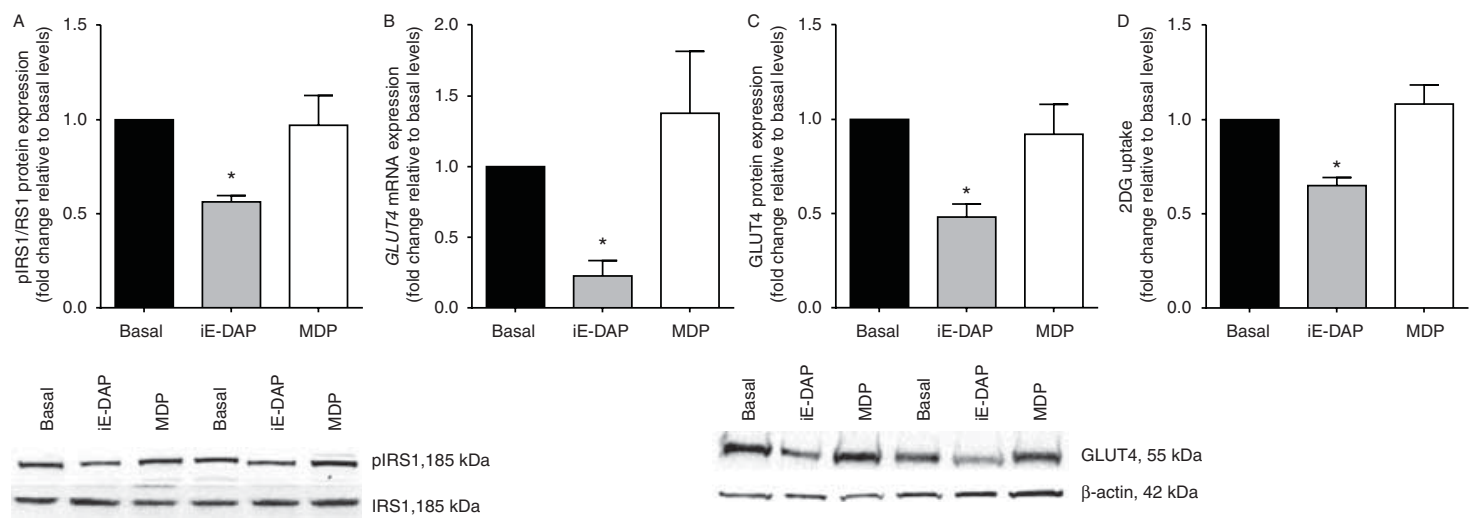

\section{Figure 10}

The NOD1 ligand iE-DAP inhibits the insulin signalling pathway. Omental adipose tissue from NGT pregnant women was incubated in the absence or presence of $5 \mu \mathrm{g} / \mathrm{ml} \mathrm{iE}$-DAP or $5 \mu \mathrm{g} / \mathrm{ml}$ MDP for $20 \mathrm{~h}$ followed by a $30 \mathrm{~min}$ incubation with $0.1 \mu \mathrm{M}$ insulin ( $n=4$ patients). (A) Phosphorylated IRS1 (pIRS1) protein expression was normalised to total IRS1, and the fold changes were calculated relative to basal levels. Data are presented as mean \pm s.E.M. ${ }^{*} P<0.05$ vs basal (paired sample comparison). A representative western blot from two patients is also shown. (B) GLUT4 gene expression was normalised to GAPDH, and the fold changes were calculated relative to basal levels. Data are presented as mean \pm s.E.M. $* P<0.05$ vs basal (paired sample comparison). (C) GLUT4 protein expression was normalised to $\beta$-actin, and the fold changes were calculated relative to basal levels. Data are presented as mean \pm s.E.M. ${ }^{*} P<0.05$ vs basal (paired sample comparison). A representative western blot from two patients is also shown. (D) 2DG uptake data are displayed as mean \pm s.E.M. ${ }^{*} P<0.05$ vs basal 2DG uptake (paired sample comparison).

Published by Bioscientifica Ltd. 
GDM have significantly higher IL8 mRNA expression in visceral adipose tissue compared with NGT women (Kuzmicki et al. 2012). Similarly, in this study, IL8 release was higher in omental adipose tissue from women with GDM compared with NGT women. In this study, ligand activation of NOD1, but not NOD2, resulted in increased expression and secretion of IL6 and IL8 from adipose tissue. Similarly, stimulation of NOD1 with a synthetic ligand Tri-DAP induces the pro-inflammatory chemokine MCP1 and RANTES and the pro-inflammatory cytokines tumour necrosis factor $\alpha$, MIP2 (human IL8 homologue) and IL6 mRNA expression in 3T3-L1 adipocytes and human primary adipocytes (Zhao et al. 2011, Zhou et al. 2012). In addition, NOD1 activation provokes adipose tissue inflammation in vivo (Schertzer et al. 2011). Collectively, these results indicate that NOD1 activation may facilitate the infiltration of leukocytes into adipose tissue, leading to adipose inflammation, a key feature of GDM pregnancies (Lappas 2013a, Oliva et al. 2013). Moreover, NOD1-mediated release of pro-inflammatory cytokines from adipose tissue may directly contribute to the insulin resistance that is evident in pregnancies complicated by GDM (Catalano et al. 2002, Colomiere et al. 2010). In keeping with this, the data presented in this paper indicates that NOD1 activation induces attenuation of insulin signalling, which leads to suppression of insulin-induced glucose uptake.

Several lines of evidence support the importance of the COX-prostaglandin pathway in the pathophysiology of type 2 diabetes. COX 2 gene expression is induced in livers of diet-induced and genetic obesity mouse models (Henkel et al. 2012). Pharmacological inhibition of COX2 has also been shown to improve insulin sensitivity in both rodents and humans (Gonzalez-Ortiz et al. 2001, Hsieh et al. 2008). Furthermore, PGE2, which is released from adipose tissue (Lappas et al. 2005a), can also attenuate insulin signalling (Henkel et al. 2009). Interestingly, genetic variation in the carbonyl reductase 3 gene, which encodes an enzyme for converting PGE2 to PGF $2 \alpha$, is associated with type 2 diabetes (Chang et al. 2012). In this study, the NOD1 ligand induced COX2 gene expression and this was associated with an increase in the secretion of PGE2 and PGF $2 \alpha$ from both subcutaneous and omental adipose tissues. Again, there was no effect of NOD2 activation on COX2 expression and prostaglandin release. This is the first study, to my knowledge, to report that NOD1 activation upregulates the COX-prostaglandin pathway in adipose tissue; however NOD1 and NOD2 activation of COX2 has previously been reported in placenta (Lappas 2013b) and macrophages (Tsai et al. 2011).
Development of excessive adipose tissue is associated with obesity and diabetes (Streuli 1999). Remodelling of the ECM is required for several aspects of adipose tissue differentiation, which is mainly mediated via the MMP systems. Proper ECM remodelling is critical for supporting adipose tissue malleability to accommodate changes in energy storage needs. In addition to their role in adipose tissue remodelling, MMPs play a role in inflammation by releasing, activating or degrading several growth factors and cytokines implicated in diabetes (Galis \& Khatri 2002). MMP9, which is released from adipose tissue (Bouloumie et al. 2001), is a key enzyme involved in these processes. Higher plasma and tissue MMP9 levels are found in obese subjects (Laimer et al. 2005) and patients with the metabolic syndrome (Goncalves et al. 2009). In this study, the NOD1 ligand induced MMP9 gene expression and secretion of pro MMP9 from both subcutaneous and omental adipose tissues. Similarly, NOD1 has been shown to induce MMP9 in human placenta (Lappas 2013b), and in vivo in the aortic root and pulmonary artery after oral administration of a NOD1 ligand (Nishio et al. 2011).

The adhesion molecules ICAM1 and VCAM1 play an important role in the development of endothelial dysfunction. Atherosclerosis is predominantly mediated by cellular adhesion molecules, which are expressed on the vascular endothelium and on circulating leukocytes in response to several inflammatory stimuli. Soluble forms of ICAM1 and VCAM1 have been found to enter the systemic circulation, as a result of proteolytic cleavage at the cell surface, releasing the extracellular domain. Indeed, sICAM1 and sVCAM1 levels are higher in insulin resistance, obesity and type 2 diabetes (Guler et al. 2002, Leinonen et al. 2003, Kent et al. 2004). There is also evidence indicating that women with GDM develop endothelial dysfunction during pregnancy (Knock et al. 1997), and despite returning to NGT, endothelial dysfunction is still evident in women 1-year post GDM pregnancy (Pleiner et al. 2007). Indeed, women with GDM have increased circulating sICAM1 and sVCAM1 levels (Mordwinkin et al. 2013). My recent studies have also shown that the expression and secretion of markers of endothelial cell dysfunction are increased in adipose tissue from women with GDM (Lappas 2014b). In this study, the NOD1 ligand iE-DAP induced adipose tissue expression and secretion of ICAM1 and VCAM1. This is the first study, to my knowledge, to report that NOD1 activation upregulates the adhesion molecules in adipose tissue. However, ligand activation of NOD1 has been shown to increase ICAM1 gene expression in human airway smooth

Published by Bioscientifica Ltd.

Downloaded from Bioscientifica.com at $04 / 26 / 2023$ 01:45:45PM via free access 
muscle cells (Kvarnhammar et al. 2013), bronchial epithelial cells (Wong et al. 2013) and human coronary artery endothelial cells (Nishio et al. 2011). In vivo, NOD1 ligands induce ICAM1 and VCAM1 gene expression in the aortic root, pulmonary artery, aorta and spleen (Nishio et al. 2011).

The NFkB signalling pathway has been shown to be a key link between inflammation and insulin resistance (Arkan et al. 2005). Similarly, my previous studies show that $\mathrm{NF \kappa B}$ is a key regulator of inflammation-induced pro-inflammatory cytokine release from adipose tissue obtained from pregnant women (Lappas et al. 2005c, Lappas 2013a). There is increasing evidence that NODs elicit many of their actions via activation of NFKB (Inohara \& Nunez 2003, Strober et al. 2006). This study also revealed that the mechanism underlying the pro-inflammatory gene expression and secretion downstream of NOD1 activation in subcutaneous and omental adipose tissues involves the NFKB signalling pathway. Specifically, the NFкB inhibitor BAY 11-7082 significantly attenuated NOD1-induced expression and secretion of IL6 and IL8 mRNAs, expression of the COX2 gene and subsequent prostaglandin release and expression and secretion of MMP9, ICAM1 and VCAM1. These data are in agreement with results from previous studies indicating an important role for NFKB in NOD1-induced adipocyte inflammation and differentiation (Zhou et al. 2012, Purohit et al. 2013).

A limitation of this study is that GDM mothers were treated with insulin to lower their blood sugar levels. This could influence the results as previous studies from my laboratory have shown differences in components of the insulin signalling pathway in adipose tissue between controls and insulin-treated GDM subjects but also between diet-controlled and insulin-managed GDM pregnancies (Colomiere et al. 2010). Nevertheless, this is, to my knowledge, the first study carried out in humans, which has identified changes in NOD1 gene expression, induced by GDM, in both omental and subcutaneous adipose tissues. In addition, the present findings demonstrate a role for NOD1 in adipose tissue inflammation and in the development of insulin resistance in pregnancies complicated by GDM. In this study, I did not measure GLUT4 expression in the membrane fraction due to limitations in the amount of sample obtained. In addition, I was unable to detect phosphorylated AKT protein expression in these samples. Thus, from these studies, I am unable to conclude that the detected GLUT4 was translocated through the membrane. Nevertheless, insulin-stimulated glucose uptake was lower in the presence of the NOD1 ligand iE-DAP.
In conclusion, the data presented in this study provide evidence that omental and subcutaneous adipose tissues obtained from women with GDM are associated with increased NOD1 expression. NOD1 activation induced expression of a number of inflammatory markers including pro-inflammatory cytokines, COX2 and subsequent PGE2 and PGF2 $\alpha$ production, the ECM remodelling enzyme MMP9 and the expression and secretion of the adhesion molecules ICAM1 and VCAM1. These actions of NOD1 were mediated by $\mathrm{NF} \kappa \mathrm{B}$. In addition, NOD1 activation impaired insulin signalling in adipose tissue. Together, these results indicate that NOD1 plays an important role in adipose tissue inflammation and insulin resistance that is evident in women with GDM.

\section{Declaration of interest}

The author declares that there is no conflict of interest that could be perceived as prejudicing the impartiality of the research reported.

\section{Funding}

M L is supported by a Career Development Fellowship by the National Health and Medical Research Council (NHMRC; grant number 1047025). This work was funded by grants from Diabetes Australia Research Trust (DART) and the Medical Research Foundation for Women and Babies.

\section{Acknowledgements}

The following are gratefully acknowledged: Gillian Barker (Department of Obstetrics and Gynaecology, University of Melbourne) for her excellent technical assistance; clinical Research Midwives Genevieve Christophers, Renee Grant, Gabrielle Fleming, Debra Jinks and Rachel Murdoch for sample collection; and the Obstetrics and Midwifery staff of the Mercy Hospital for Women for their co-operation.

\section{References}

Arkan MC, Hevener AL, Greten FR, Maeda S, Li ZW, Long JM, WynshawBoris A, Poli G, Olefsky J \& Karin M 2005 IKK- $\beta$ links inflammation to obesity-induced insulin resistance. Nature Medicine 11 191-198. (doi:10.1038/nm1185)

Bouloumie A, Sengenes C, Portolan G, Galitzky J \& Lafontan M 2001 Adipocyte produces matrix metalloproteinases 2 and 9: involvement in adipose differentiation. Diabetes 50 2080-2086. (doi:10.2337/diabetes. 50.9.2080)

Cani PD, Amar J, Iglesias MA, Poggi M, Knauf C, Bastelica D, Neyrinck AM, Fava F, Tuohy KM, Chabo C et al. 2007 Metabolic endotoxemia initiates obesity and insulin resistance. Diabetes 56 1761-1772. (doi:10.2337/ db06-1491)

Catalano PM, Nizielski SE, Shao JH, Preston L, Qiao LP \& Friedman JE 2002 Downregulated IRS-1 and PPAR $\gamma$ in obese women with gestational diabetes: relationship to FFA during pregnancy. American Journal of Physiology. Endocrinology and Metabolism 282 E522-E533. (doi:10.1152/ ajpendo.00124.2001)

Chamaillard M, Hashimoto M, Horie Y, Masumoto J, Qiu S, Saab L, Ogura Y, Kawasaki A, Fukase K, Kusumoto S et al. 2003 An essential role for NOD1 in

Published by Bioscientifica Ltd. 
host recognition of bacterial peptidoglycan containing diaminopimelic acid. Nature Immunology 4 702-707. (doi:10.1038/ni945)

Chang YC, Liu PH, Tsai YC, Chiu YF, Shih SR, Ho LT, Lee WJ, Lu CH, Quertermous T, Curb JD et al. 2012 Genetic variation in the carbonyl reductase 3 gene confers risk of type 2 diabetes and insulin resistance: a potential regulator of adipogenesis. Journal of Molecular Medicine 90 847-858. (doi:10.1007/s00109-012-0898-8)

Colomiere M, Permezel M \& Lappas M 2010 Diabetes and obesity during pregnancy alter insulin signalling and glucose transporter expression in maternal skeletal muscle and subcutaneous adipose tissue. Journal of Molecular Endocrinology 44 213-223. (doi:10.1677/JME-09-0091)

Dabelea D, Hanson RL, Lindsay RS, Pettitt DJ, Imperatore G, Gabir MM, Roumain J, Bennett PH \& Knowler WC 2000 Intrauterine exposure to diabetes conveys risks for type 2 diabetes and obesity: a study of discordant sibships. Diabetes 49 2208-2211. (doi:10.2337/diabetes. 49.12.2208)

Ferrara A 2007 Increasing prevalence of gestational diabetes mellitus: a public health perspective. Diabetes Care 30(Suppl 2) S141-S146. (doi:10.2337/dc07-s206)

Fox CS, Massaro JM, Hoffmann U, Pou KM, Maurovich-Horvat P, Liu CY, Vasan RS, Murabito JM, Meigs JB, Cupples LA et al. 2007 Abdominal visceral and subcutaneous adipose tissue compartments: association with metabolic risk factors in the Framingham Heart Study. Circulation 116 39-48. (doi:10.1161/CIRCULATIONAHA.106.675355)

Galis ZS \& Khatri JJ 2002 Matrix metalloproteinases in vascular remodeling and atherogenesis - the good, the bad, and the ugly. Circulation Research 90 251-262. (doi:10.1161/hh0302.105345)

Garvey WT, Maianu L, Zhu JH, Hancock JA \& Golichowski AM 1993 Multiple defects in the adipocyte glucose transport system cause cellular insulin resistance in gestational diabetes. Heterogeneity in the number and a novel abnormality in subcellular localization of GLUT4 glucose transporters. Diabetes 42 1773-1785. (doi:10.2337/ diab.42.12.1773)

Girardin SE, Boneca IG, Viala J, Chamaillard M, Labigne A, Thomas G, Philpott DJ \& Sansonetti PJ 2003 Nod2 is a general sensor of peptidoglycan through muramyl dipeptide (MDP) detection. Journal of Biological Chemistry 278 8869-8872. (doi:10.1074/jbc.C200651200)

Goncalves FM, Jacob-Ferreira AL, Gomes VA, Casella-Filho A, Chagas AC, Marcaccini AM, Gerlach RF \& Tanus-Santos JE 2009 Increased circulating levels of matrix metalloproteinase (MMP)-8, MMP-9, and pro-inflammatory markers in patients with metabolic syndrome. Clinica Chimica Acta 403 173-177. (doi:10.1016/j.cca.2009.02.013)

Gonzalez-Ortiz M, Martinez-Abundis E, Balcazar-Munoz BR \& RoblesCervantes JA 2001 Inhibition of cyclooxygenase-1 or -2 on insulin sensitivity in healthy subjects. Hormone and Metabolic Research $\mathbf{3 3}$ 250-253. (doi:10.1055/s-2001-14949)

Guler S, Cakir B, Demirbas B, Yonem A, Odabasi E, Onde U, Aykut O \& Gursoy G 2002 Plasma soluble intercellular adhesion molecule 1 levels are increased in type 2 diabetic patients with nephropathy. Hormone Research 58 67-70. (doi:10.1159/000064664)

Henkel J, Neuschafer-Rube F, Pathe-Neuschafer-Rube A \& Puschel GP 2009 Aggravation by prostaglandin $\mathrm{E}_{2}$ of interleukin-6-dependent insulin resistance in hepatocytes. Hepatology 50 781-790. (doi:10.1002/hep. 23064)

Henkel J, Frede K, Schanze N, Vogel H, Schurmann A, Spruss A, Bergheim I $\&$ Puschel GP 2012 Stimulation of fat accumulation in hepatocytes by $\mathrm{PGE}_{2}$-dependent repression of hepatic lipolysis, $\beta$-oxidation and VLDLsynthesis. Laboratory Investigation 92 1597-1606. (doi:10.1038/labinvest.2012.128)

Hsieh PS, Tsai HC, Kuo CH, Chan JY, Shyu JF, Cheng WT \& Liu TT 2008 Selective COX2 inhibition improves whole body and muscular insulin resistance in fructose-fed rats. European Journal of Clinical Investigation 38 812-819. (doi:10.1111/j.1365-2362.2008.02026.x)

Inohara N \& Nunez G 2003 NODs: intracellular proteins involved in inflammation and apoptosis. Nature Reviews. Immunology 3 371-382. (doi:10.1038/nri1086)
Kautzky-Willer A, Fasching P, Jilma B, Waldhausl W \& Wagner OF 1997 Persistent elevation and metabolic dependence of circulating E-selectin after delivery in women with gestational diabetes mellitus. Journal of Clinical Endocrinology and Metabolism 82 4117-4121. (doi:10.1210/ jcem.82.12.4419)

Kent JW, Comuzzie AG, Mahaney MC, Almasy L, Rainwater DL, VandeBerg JL, MacCluer JW \& Blangero J 2004 Intercellular adhesion molecule-1 concentration is genetically correlated with insulin resistance, obesity, and HDL concentration in Mexican Americans. Diabetes 53 2691-2695. (doi:10.2337/diabetes.53.10.2691)

Kern PA, Ranganathan S, Li C, Wood L \& Ranganathan G 2001 Adipose tissue tumor necrosis factor and interleukin-6 expression in human obesity and insulin resistance. American Journal of Physiology. Endocrinology and Metabolism 280 E745-E751.

Kim C, Berger DK \& Chamany S 2007 Recurrence of gestational diabetes mellitus: a systematic review. Diabetes Care 30 1314-1319. (doi:10.2337/dc06-2517)

Knock GA, McCarthy AL, Lowy C \& Poston L 1997 Association of gestational diabetes with abnormal maternal vascular endothelial function. British Journal of Obstetrics and Gynaecology 104 229-234. (doi:10.1111/j.1471-0528.1997.tb11051.x)

Krauss T, Emons G, Kuhn W \& Augustin HG 2002 Predictive value of routine circulating soluble endothelial cell adhesion molecule measurements during pregnancy. Clinical Chemistry 48 1418-1425.

Kuzmicki M, Telejko B, Szamatowicz J, Zonenberg A, Nikolajuk A, Kretowski A \& Gorska M 2009 High resistin and interleukin-6 levels are associated with gestational diabetes mellitus. Gynecological Endocrinology 25 258-263. (doi:10.1080/09513590802653825)

Kuzmicki M, Telejko B, Wawrusiewicz-Kurylonek N, Citko A, Lipinska D, Pliszka J, Wilk J, Kalejta K, Lemancewicz A, Grabiec M et al. 2012 The expression of suppressor of cytokine signaling 1 and 3 in fat and placental tissue from women with gestational diabetes. Gynecological Endocrinology 28 841-844. (doi:10.3109/09513590.2012.683055)

Kvarnhammar AM, Tengroth L, Adner M \& Cardell LO 2013 Innate immune receptors in human airway smooth muscle cells: activation by TLR1/2, TLR3, TLR4, TLR7 and NOD1 agonists. PLoS ONE 8 e68701. (doi:10.1371/journal.pone.0068701)

Laimer M, Kaser S, Kranebitter M, Sandhofer A, Muhlmann G, Schwelberger H, Weiss H, Patsch JR \& Ebenbichler CF 2005 Effect of pronounced weight loss on the nontraditional cardiovascular risk marker matrix metalloproteinase-9 in middle-aged morbidly obese women. International Journal of Obesity 29 498-501. (doi:10.1038/sj.ijo.0802897)

Lain KY \& Catalano PM 2007 Metabolic changes in pregnancy. Clinical Obstetrics and Gynecology 50 938-948. (doi:10.1097/GRF. Ob013e31815a5494)

Laitinen K, Poussa T, Isolauri E, Nutrition AMI \& Intestinal Microbiota G 2009 Probiotics and dietary counselling contribute to glucose regulation during and after pregnancy: a randomised controlled trial. British Journal of Nutrition 101 1679-1687. (doi:10.1017/S0007114508111461)

Lappas M 2013 $a$ NOD1 and NOD2 regulate proinflammatory and prolabor mediators in human fetal membranes and myometrium via nuclear factor- $\kappa$ B. Biology of Reproduction 89 14. (doi:10.1095/biolreprod.113. 110056)

Lappas M 2013b Activation of inflammasomes in adipose tissue of women with gestational diabetes. Molecular and Cellular Endocrinology $\mathbf{3 8 2}$ 74-83. (doi:10.1016/j.mce.2013.09.011)

Lappas M 2014a Effect of pre-existing maternal obesity, gestational diabetes and adipokines on the expression of genes involved in lipid metabolism in adipose tissue. Metabolism 63 250-262. (doi:10.1016/ j.metabol.2013.10.001)

Lappas M $2014 b$ Markers of endothelial cell dysfunction are increased in human omental adipose tissue from women with pre-existing maternal obesity and gestational diabetes. Metabolism 63 860-873. (doi:10.1016/ j.metabol.2014.03.007)

Lappas M, Permezel M \& Rice GE 2005 a Leptin and adiponectin stimulate the release of proinflammatory cytokines and prostaglandins from 
human placenta and maternal adipose tissue via nuclear factor-кB, peroxisomal proliferator-activated receptor- $\gamma$ and extracellularly regulated kinase 1/2. Endocrinology 146 3334-3342. (doi:10.1210/ en.2005-0406)

Lappas M, Yee K, Permezel M \& Rice GE $2005 b$ Release and regulation of leptin, resistin and adiponectin from human placenta, fetal membranes, and maternal adipose tissue and skeletal muscle from normal and gestational diabetes mellitus-complicated pregnancies. Journal of Endocrinology 186 457-465. (doi:10.1677/joe.1.06227)

Lappas M, Yee K, Permezel M \& Rice GE 2005c Sulfasalazine and BAY

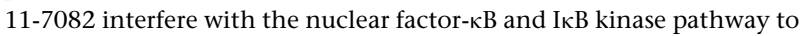
regulate the release of proinflammatory cytokines from human adipose tissue and skeletal muscle in vitro. Endocrinology 146 1491-1497. (doi:10.1210/en.2004-0809)

Lappas M, Permezel M \& Rice GE 2006 15-Deoxy- $\Delta 12,14$-prostaglandin $J_{2}$ and troglitazone regulation of the release of phospholipid metabolites, inflammatory cytokines and proteases from human gestational tissues. Placenta 27 1060-1072. (doi:10.1016/j.placenta.2005.11.009)

Lappas M, Andrikopoulos S \& Permezel M 2012 Hypoxanthine-xanthine oxidase down-regulates GLUT1 transcription via SIRT1 resulting in decreased glucose uptake in human placenta. Journal of Endocrinology 213 49-57. (doi:10.1530/JOE-11-0355)

Leinonen E, Hurt-Camejo E, Wiklund O, Hulten LM, Hiukka A \& Taskinen MR 2003 Insulin resistance and adiposity correlate with acute-phase reaction and soluble cell adhesion molecules in type 2 diabetes. Atherosclerosis 166 387-394. (doi:10.1016/S00219150(02)00371-4)

Mordwinkin NM, Ouzounian JG, Yedigarova L, Montoro MN, Louie SG \& Rodgers KE 2013 Alteration of endothelial function markers in women with gestational diabetes and their fetuses. Journal of Maternal-Fetal \& Neonatal Medicine 26 507-512. (doi:10.3109/14767058.2012.736564)

Morisset AS, Dube MC, Cote JA, Robitaille J, Weisnagel SJ \& Tchernof A 2011 Circulating interleukin-6 concentrations during and after gestational diabetes mellitus. Acta Obstetricia et Gynecologica Scandinavica 90 524-530. (doi:10.1111/j.1600-0412.2011.01094.x)

Nieto-Vazquez I, Fernandez-Veledo S, de Alvaro C \& Lorenzo M 2008 Dual role of interleukin-6 in regulating insulin sensitivity in murine skeletal muscle. Diabetes 57 3211-3221. (doi:10.2337/db07-1062)

Nishio H, Kanno S, Onoyama S, Ikeda K, Tanaka T, Kusuhara K, Fujimoto Y, Fukase K, Sueishi K \& Hara T 2011 Nod1 ligands induce site-specific vascular inflammation. Arteriosclerosis, Thrombosis, and Vascular Biology 31 1093-1099. (doi:10.1161/ATVBAHA.110.216325)

Oliva K, Barker G, Rice GE, Bailey MJ \& Lappas M 2013 2D-DIGE to identify proteins associated with gestational diabetes in omental adipose tissue. Journal of Endocrinology 218 165-178. (doi:10.1530/JOE-13-0010)

Pleiner J, Mittermayer F, Langenberger H, Winzer C, Schaller G, Pacini G, Kautzky-Willer A, Tura A \& Wolzt M 2007 Impaired vascular nitric oxide bioactivity in women with previous gestational diabetes. Wiener Klinische Wochenschrift 119 483-489. (doi:10.1007/s00508-007-0838-8)

Pradhan AD, Manson JE, Rifai N, Buring JE \& Ridker PM 2001 C-reactive protein, interleukin 6 , and risk of developing type 2 diabetes mellitus. Journal of the American Medical Association 286 327-334. (doi:10.1001/ jama.286.3.327)
Purohit JS, Hu P, Burke SJ, Collier JJ, Chen JG \& Zhao L 2013 The effects of NOD activation on adipocyte differentiation. Obesity 21 737-747. (doi:10.1002/oby.20275)

Radaelli T, Uvena-Celebrezze J, Minium J, Huston-Presley L, Catalano P \& Hauguel-de Mouzon S 2006 Maternal interleukin-6: marker of fetal growth and adiposity. Journal of the Society for Gynecologic Investigation 13 53-57. (doi:10.1016/j.jsgi.2005.10.003)

Schertzer JD, Tamrakar AK, Magalhaes JG, Pereira S, Bilan PJ, Fullerton MD, Liu Z, Steinberg GR, Giacca A, Philpott DJ et al. 2011 NOD1 activators link innate immunity to insulin resistance. Diabetes 60 2206-2215. (doi:10.2337/db11-0004)

Senn JJ, Klover PJ, Nowak IA \& Mooney RA 2002 Interleukin-6 induces cellular insulin resistance in hepatocytes. Diabetes 51 3391-3399. (doi:10.2337/diabetes.51.12.3391)

Sobngwi E, Boudou P, Mauvais-Jarvis F, Leblanc H, Velho G, Vexiau P, Porcher R, Hadjadj S, Pratley R, Tataranni PA et al. 2003 Effect of a diabetic environment in utero on predisposition to type 2 diabetes. Lancet 361 1861-1865. (doi:10.1016/S0140-6736(03)13505-2)

Streuli C 1999 Extracellular matrix remodelling and cellular differentiation. Current Opinion in Cell Biology 11 634-640. (doi:10.1016/S09550674(99)00026-5)

Strober W, Murray PJ, Kitani A \& Watanabe T 2006 Signalling pathways and molecular interactions of NOD1 and NOD2. Nature Reviews. Immunology 6 9-20. (doi:10.1038/nri1747)

Tsai WH, Huang DY, Yu YH, Chen CY \& Lin WW 2011 Dual roles of NOD2 in TLR4-mediated signal transduction and -induced inflammatory gene expression in macrophages. Cellular Microbiology 13 717-730. (doi:10.1111/j.1462-5822.2010.01567.x)

Winzer C, Wagner O, Festa A, Schneider B, Roden M, Bancher-Todesca D, Pacini G, Funahashi T \& Kautzky-Willer A 2004 Plasma adiponectin, insulin sensitivity, and subclinical inflammation in women with prior gestational diabetes mellitus. Diabetes Care 27 1721-1727. (doi:10.2337/diacare.27.7.1721)

Wong CK, Hu SQ, Leung KM, Dong J, He L, Chu YJ, Chu IM, Qiu HN, Liu KY \& Lam CW 2013 NOD-like receptors mediated activation of eosinophils interacting with bronchial epithelial cells: a link between innate immunity and allergic asthma. Cellular \& Molecular Immunology 10 317-329. (doi:10.1038/cmi.2012.77)

Yi-Jun Z, Ai L, Yu-Ling S, Yan L \& Hui Y 2012 Nucleotide-binding oligomerization domain-1 ligand induces inflammation and attenuates glucose uptake in human adipocytes. Chinese Medical Sciences Journal 27 $147-152$.

Yu F, Xue YM, Li CZ, Shen J, Gao F, Yu YH \& Fu XJ 2007 Association of serum interleukin- 6 and high-sensitivity C-reactive protein levels with insulin resistance in gestational diabetes mellitus. Nan Fang $\mathrm{Yi} \mathrm{Ke} \mathrm{Da}$ Хие Хие Вао 27 799-801.

Zhao L, Hu P, Zhou Y, Purohit J \& Hwang D 2011 NOD1 activation induces proinflammatory gene expression and insulin resistance in 3T3-L1 adipocytes. American Journal of Physiology. Endocrinology and Metabolism 301 E587-E598. (doi:10.1152/ajpendo.00709.2010)

Zhou YJ, Zhou H, Li Y \& Song YL 2012 NOD1 activation induces innate immune responses and insulin resistance in human adipocytes. Diabetes \& Metabolism 38 538-543. (doi:10.1016/j.diabet.2012.08.001)

Received in final form 5 May 2014

Accepted 8 May 2014

Accepted Preprint published online 14 May 2014 http://joe.endocrinology-journals.org DOI: 10.1530/JOE-14-0179
C 2014 Society for Endocrinology Printed in Great Britain 